\title{
A technique for the separation of the most recently deposited nacreous layer in Mytilus californianus shells for trace metal analysis
}

\section{Técnica para la separación de la capa de nácar recientemente depositada en la concha de Mytilus californianus para el análisis de metales traza}

\author{
L.E. Rivero \\ M.L. Lares* \\ Departamento de Ecología \\ Centro de Investigación Científica y de Educación Superior de Ensenada \\ Ensenada, CP 22800, BC, México \\ *E-mail: llares@cicese.mx
}

Recibido en febrero de 2003; aceptado en febrero de 2004

\begin{abstract}
A new method to separate a section of the most recently deposited nacreous layer from the rest of the shell of Mytilus californianus was developed. Techniques described for other mussel species proved unsuitable for this species. In this new method, the shells are soaked in $30 \%$ hydrogen peroxide for $10-15 \mathrm{~min}$ at $80-85^{\circ} \mathrm{C}$ to eliminate the periostracum, a potential source of trace metal contamination. Next, the shells are heated in a muffle furnace at $350^{\circ} \mathrm{C}$ for $1 \mathrm{~h}$ to separate the nacreous layer from the calcite layer. Finally, the nacreous band is easily separated from the rest of the shell by gently tapping it with a stainless steel needle. This is a simple and fast method that is proposed for trace metal monitoring purposes using M. californianus shells. To illustrate the application of the method, results from an experiment performed in our laboratory, in which mussels were exposed to two different $\mathrm{Cd}$ concentrations for 60 days and their shells processed by this technique, are included. The most recently deposited nacreous layer showed significant increases in Cd concentrations, which were proportional to the exposed ambient concentrations.
\end{abstract}

Key words: Mytilus californianus, shell, nacreous layer, cadmium.

\section{Resumen}

Se desarrolló un nuevo método para separar una sección de la capa de nácar recientemente depositada del resto de la concha de Mytilus californianus. Los métodos descritos para otras especies de mejillones demostraron no ser apropiados para las conchas de esta especie. En este nuevo método, las conchas son sumergidas en peróxido de hidrógeno al $30 \%$ por $10-15$ min a $80-85^{\circ} \mathrm{C}$ para eliminar el periostraco, una fuente potencial de contaminación por metales traza. Enseguida, las conchas son calentadas en una mufla a $350^{\circ} \mathrm{C}$ por $1 \mathrm{~h}$ para separar la capa de nácar de la calcítica. Finalmente, la banda de nácar recientemente depositada es fácilmente separada del resto de la concha, al golpearla suavemente con una aguja de acero inoxidable. Éste es un método simple y rápido propuesto para el monitoreo ambiental de metales traza utilizando las conchas de M. californianus. Como un ejemplo de la aplicación de este método, se presentan los resultados de un experimento realizado en laboratorio, en el que los mejillones fueron expuestos a dos diferentes concentraciones de $\mathrm{Cd}$ por 60 días y sus conchas fueron procesadas por medio de esta técnica. La capa de nácar más recientemente depositada mostró incrementos significativos en sus concentraciones de Cd, los cuales fueron proporcionales al aumento en las concentraciones ambientales de exposición.

Palabras clave: Mytilus californianus, concha, capa de nácar, cadmio.

\section{Introduction}

Mytilus californianus is a characteristic organism of highwave energy areas on the Pacific coast, where it is abundant, while other mussel species are absent; hence, this species could represent a good alternative for trace metal monitoring in these environments. Usually, mussel soft tissues are analyzed for their metal content, but in the case of $M$. californianus they show high variability, even in time spans of days (Lares and Orians, 1997), and their usefulness as a medium-term indicator

\section{Introducción}

Mytilus californianus es un organismo característico de las zonas de alta energía en las costas del Pacífico, donde se encuentra en abundancia mientras que otras especies de mejillones están ausentes; por tanto, esta especie podría ser una buena alternativa para el estudio de metales traza en estos ambientes. Comúnmente, los tejidos blandos de los mejillones son analizados para determinar el contenido de metales, pero en el caso de $M$. californianus presentan una alta variabilidad, 
has been questioned. For this reason, their shells could be a better alternative for medium-term (months) studies, since they are expected to retain metals for longer periods of time once the metals are incorporated into the calcium carbonate matrix.

Mytilus californianus has a shell composed of four principal layers (fig. 1a): the periostracum (entirely organic), nacreous layer (aragonite), and outer and inner prismatic layers (calcite) (Dodd, 1964). In order to provide an index of bioavailability, it is essential that the shell structure chosen for the analysis has not been exposed to either particulate or dissolved metals in the water column. Several authors (Sturesson, 1978; Bourgoin, 1990; Puente et al., 1996) have pointed out the advantage of analyzing metals associated with the nacreous layer, instead of the periostracum or calcite layer. This layer is located in the internal part of the shell and is isolated from the external medium (seawater); therefore, metals incorporated into the nacreous layer will represent only those accumulated by the organism metabolism (Bourgoin, 1990). On the other hand, the periostracum has the disadvantage of having direct contact with seawater, and could leave the outer calcite layer exposed if it is eroded.

The separation of the internal shell layer of $M$. californianus for its use in trace metal analyses has not been previously reported, although Sturesson (1976) and Bourgoin (1988) developed a similar approach using shells of M. edulis. However, it is known that M. edulis and M. californianus shells present several differences; while $M$. edulis has a carbonate shell composed of an outer prismatic (calcite) layer and an inner nacreous (aragonite) layer, the $M$. californianus carbonate shell has an extra inner prismatic layer (Dodd, 1964). Therefore, the aim of the present study was to develop a suitable clean technique for the separation of a nacreous layer section that represents the most recent growth of $M$. californianus shells.

\section{Materials and methods}

Mussels of 50-80 $\mathrm{mm}$ in length collected from Amphitrite Point, Canada, and from Ensenada, Mexico, were used in this study. Their shells were separated from the soft tissue with a stainless steel scalpel, cleaned from all extraneous material with a plastic brush under a flow of deionized distilled water (DDW) and, finally, air-dried for 2 days. To remove the periostracum, experiments were run using $30 \% \mathrm{H}_{2} \mathrm{O}_{2}$ (ACS reagent, Sigma-Aldrich) at different temperatures $(18,60,65,70,75$, $80,85,90,95$ and $\left.100^{\circ} \mathrm{C}\right)$ and time intervals $(5,10$ and $15 \mathrm{~min}$, 12 and $24 \mathrm{~h}$ ). Once the periostracum was removed, a final rinse with $30 \% \mathrm{H}_{2} \mathrm{O}_{2}$ (puriss. pa, Fluka) and DDW was performed. Once the valves were clean, they were heated in a muffle furnace to separate the nacreous layer from the calcitic layer. To find the optimum conditions for this treatment, several temperatures $\left(300,350,400\right.$ and $\left.500^{\circ} \mathrm{C}\right)$ and different time intervals $(0.5,1.0,1.5,2.0,2.5$ and $18.0 \mathrm{~h})$ were tested on a minimum of five valves. Finally, the most recently deposited nacreous band was separated by gently tapping with a stainless steel needle. aun en lapsos de tiempo de días (Lares y Orians, 1997), lo que ha cuestionado su utilidad como indicadores de mediano plazo. Por esta razón, sus conchas podrían ser una mejor alternativa para estudios de mediano plazo (meses), ya que se supone que retienen metales por periodos de tiempo más largos una vez que éstos han sido incorporados en la matriz de carbonato de calcio.

La concha de $M$. californianus está compuesta de cuatro capas principales (fig. 1a): el periostraco (totalmente orgánico), la capa de nácar (aragonita), y las capas prismáticas (calcita) interior y exterior (Dodd, 1964). Para proporcionar un índice de biodisponibilidad, es indispensable que la estructura de la concha seleccionada para el análisis no haya sido expuesta a metales particulados o disueltos en la columna de agua. Varios autores (Sturesson, 1978; Bourgoin, 1990; Puente et al., 1996) han comentado las ventajas de analizar metales asociados con la capa de nácar, en vez de con el periostraco o la capa calcítica. Esta capa se localiza en la parte interna de la concha y está aislada del medio exterior (agua de mar), lo que significa que los metales incorporados en la capa de nácar representarán sólo los acumulados por el metabolismo del organismo (Bourgoin, 1990). El periostraco, por otro lado, tiene la desventaja de estar en contacto directo con el agua de mar, quedando expuesta la capa calcítica en caso de erosión.

No existe información sobre la separación de la capa interna de la concha de $M$. californianus para su uso en análisis de metales traza, aunque Sturesson (1976) y Bourgoin (1988) desarrollaron un método similar para conchas de M. edulis. Sin embargo, se sabe que las conchas de estas dos especies son distintas: M. edulis tiene una concha de carbonato compuesta de una capa prismática (calcita) exterior y una capa de nácar (aragonita) interior, mientras que la concha de carbonato de $M$. californianus tiene una capa prismática interna adicional (Dodd, 1964). Por tanto, el objetivo de este trabajo fue desarrollar una técnica limpia adecuada para separar una sección de la capa de nácar que represente el crecimiento más reciente de la concha de $M$. californianus.

\section{Materiales y métodos}

Para este estudio se utilizaron mejillones de 50 a $80 \mathrm{~mm}$ de largo recolectados en Punta Amphitrite, Canadá, y Ensenada, México. Las conchas fueron separadas del tejido blando con un bisturí de acero inoxidable; se les quitó todo el material externo con un cepillo de plástico bajo un flujo de agua destilada y desionizada (ADD) y se dejaron secar al aire libre durante dos días. Para eliminar el periostraco, los experimentos se llevaron a cabo utilizando $\mathrm{H}_{2} \mathrm{O}_{2}$ al $30 \%$ (reactivo ACS, Sigma-Aldrich) a diferentes temperaturas $(18,60,65,70,75,80,85,90,95$ y $\left.100^{\circ} \mathrm{C}\right)$ e intervalos de tiempo $(5,10$ y $15 \mathrm{~min}, 12$ y $24 \mathrm{~h})$. Una vez eliminado el periostraco, se realizó un último enjuague con $\mathrm{H}_{2} \mathrm{O}_{2}$ a $30 \%$ (Fluka, puriss. pa) y ADD. Ya limpias, las valvas se calentaron en una mufla para separar la capa de nácar de la calcítica. Para determinar las condiciones óptimas para este tratamiento, se sometieron un mínimo de cinco valvas a varias 
This band is located in the internal face of the valve, in the direction of the growth of the organism and adjacent to the internal part of the calcite layer (5 and 2 of fig. 1a, b, respectively).

In order to analyze $\mathrm{Cd}$ for the experiment presented as an example, the material of 10 valves was pooled and digested with $0.5 \mathrm{~mL}$ of $6 \mathrm{M} \mathrm{HCl}$ and $1 \mathrm{~mL}$ of $7 \mathrm{M} \mathrm{HNO}_{3}$ (both TraceMetal) at $75^{\circ} \mathrm{C}$, evaporated until nearly dry and redissolved in $1 \mathrm{~mL}$ of $1 \mathrm{M} \mathrm{HNO}_{3}$ (TraceMetal). Cadmium was determined by graphite furnace atomic absorption spectrophotometry (GFAAS; Varian AA300/400) with Zeeman background correction. The standard additions technique was used to reduce matrix effects.

\section{Results and discussion}

Bourgoin (1988) developed a technique that uses only heat to separate the calcite from the nacreous layer. However, with this method the periostracum ashes remain next to the shells after they have been processed. Since the periostracum can accumulate several metals (e.g., $\mathrm{Cd}$ and $\mathrm{Pb}$ ) to levels higher than the nacreous layer (Sturesson, 1976, 1978), these ashes could represent a potential contamination source if they ever come in contact with the nacreous layer. Hence, one of the improvements of the present method is the removal of the protein matrix that comprises the periostracum before the physical separation of the nacreous layer is carried out. According to our experiments, the best alternative to remove the periostracum from the shell, without affecting the calcium carbonate matrix (Babukutty and Chacko, 1992), was soaking the valves in $30 \% \mathrm{H}_{2} \mathrm{O}_{2}$ at $80-85^{\circ} \mathrm{C}$ during $10-15 \mathrm{~min}$. The rapidness with which the periostracum is separated has the additional advantage of allowing the processing of a large number of shells in a short period of time. At lower temperatures the periostracum was not removed $\left(60-70^{\circ} \mathrm{C}\right)$, or was only partially eliminated $\left(70-80^{\circ} \mathrm{C}\right)$. Increasing the $\mathrm{H}_{2} \mathrm{O}_{2}$ digestion time (12 and $\left.24 \mathrm{~h}\right)$ at room temperature $\left(18^{\circ} \mathrm{C}\right)$ only partially removed the periostracum, whereas at temperatures higher than $85^{\circ} \mathrm{C}$ the recently deposited nacreous layer band was partially lost.

The section of the nacreous layer isolated in this work (fig. 1) was different from that proposed by Bourgoin (1988) for $M$. edulis. This author obtained the sample by scraping the entire internal surface of the nacreous layer at a maximum depth of $0.1 \mathrm{~mm}$. In the present work, it was observed that most of the valves of $M$. californianus exhibited a certain degree of acidification (chalky appearance) as well as internal repairs (purple coloration), in addition to the extra inner prismatic layer that M. californianus presents (fig. 1a); therefore, the scraping of the entire nacreous layer surface was not suitable for the analysis of shells from this species. Acidification and repairs were not observed in the zone of interest where the highest incorporation of $\mathrm{CaCO}_{3}$ to the aragonite layer occurs (Crenshaw, 1980). A consequence of acidification is the dissolution of the recently deposited $\mathrm{CaCO}_{3}$ (Wilbur and Saleuddin, 1983 ) and, hence, of the metals associated with this material as temperaturas $\left(300,350,400\right.$ y $\left.500^{\circ} \mathrm{C}\right)$ durante diferentes intervalos de tiempo $(0.5,1.0,1.5,2.0,2.5$ y $18.0 \mathrm{~h})$. Finalmente, la banda de nácar más reciente fue separada del resto de la concha al golpearla suavemente con una aguja de acero inoxidable. Esta banda se localiza en la cara interna de la valva, en la dirección del crecimiento del organismo y adyacente a la parte interna de la capa calcítica ( 5 y 2 de la fig. 1a, b, respectivamente).

Para el análisis de $\mathrm{Cd}$ en las conchas, se juntó el material de 10 valvas, el cual fue digerido con $0.5 \mathrm{~mL}$ de $\mathrm{HCl} 6 \mathrm{M}$ y $1 \mathrm{~mL}$ de $\mathrm{HNO}_{3} 7 \mathrm{M}$ (ambos TraceMetal) a $75^{\circ} \mathrm{C}$, evaporado hasta casi seco y redisuelto en $1 \mathrm{~mL}$ de $\mathrm{HNO}_{3} 1 \mathrm{M}$ (TraceMetal). El Cd se determinó mediante espectrofotometría de absorción atómica con horno de grafito (GFAAS; Varian AA300/400), con corrección de fondo por efecto Zeeman. Se utilizó la técnica de adiciones estándar para reducir los efectos de matriz.

\section{Resultados y discusión}

Bourgoin (1988) desarrolló una técnica que utiliza sólo calor para separar la capa calcítica de la de nácar; sin embargo, con este método las cenizas del periostraco permanecen junto a las conchas después de haber sido procesadas. En vista de que el periostraco puede acumular mayores niveles de varios metales (e.g., $\mathrm{Cd} \mathrm{y} \mathrm{Pb}$ ) que la capa de nácar (Sturesson, 1976, 1978), estas cenizas pudieran representar una fuente potencial de contaminación si llegaran a tener contacto con la capa de nácar. Por tanto, una de las ventajas de nuestro método es la eliminación de la matriz de proteína que forma el periostraco antes de realizar la separación física de la capa de nácar. Según nuestros experimentos, la mejor alternativa para eliminar el periostraco de la concha sin afectar la matriz de carbonato de calcio (Babukutty y Chacko, 1992), fue sumergir las valvas en $\mathrm{H}_{2} \mathrm{O}_{2}$ al $30 \%$ a $80-85^{\circ} \mathrm{C}$ durante $10-15 \mathrm{~min}$. La rapidez con la cual se separa el periostraco tiene la ventaja adicional de permitir el procesamiento de un gran número de conchas en poco tiempo. A menores temperaturas el periostraco no fue eliminado $\left(60-70^{\circ} \mathrm{C}\right)$, o fue parcialmente eliminado $\left(70-80^{\circ} \mathrm{C}\right)$. Un tiempo mayor de digestión en $\mathrm{H}_{2} \mathrm{O}_{2}(12$ y 24 h) a temperatura ambiente $\left(18^{\circ} \mathrm{C}\right)$ sólo eliminó parcialmente el periostraco, mientras que a temperaturas mayores que $85^{\circ} \mathrm{C}$ se perdió parcialmente la capa de nácar recién depositada.

La capa de nácar aislada en este trabajo (fig. 1) fue diferente a la propuesta por Bourgoin (1988) para M. edulis. Este autor obtuvo la muestra raspando toda la superficie interna de la capa de nácar a una profundidad máxima de $0.1 \mathrm{~mm}$. En el presente trabajo, se observó que la mayoría de las valvas de $M$. californianus mostraron un cierto grado de acidificación (apariencia gredosa), así como reparaciones internas (color púrpura), aparte de la capa prismática interna adicional característica de esta especie (fig. 1a); por tanto, el raspado de toda la capa de nácar no resultó ser apropiado para el análisis de conchas de $M$. californianus. No se observaron acidificación y reparaciones en la zona de interés, donde ocurre la mayor incorporación de $\mathrm{CaCO}_{3}$ a la capa de aragonita 
well. Presence of repairs may indicate that the seawater could have been in contact with the internal face of the shell, and the trace elements deposited in the nacreous layer may then represent a passive incorporation of metals into this layer, in addition to that resulting from the metabolism of the organism. For this reason, it was decided to separate only a band instead of scraping the entire internal surface of the nacreous layer, as reported by Bourgoin (1988).

The procedure for the optimum separation of the most recently deposited section of the nacreous layer involves heating the shells in a muffle furnace at $350^{\circ} \mathrm{C}$ for $1 \mathrm{~h}$. With this treatment the valves preserved their integrity (which facilitated the handling) and the nacreous section of interest remained essentially intact, which allowed its easy separation from the rest of the shell by gently tapping it with a stainless steel needle. The use of higher temperatures and longer times $\left(400^{\circ} \mathrm{C}\right.$ for $18 \mathrm{~h}$, as suggested by Bourgoin, 1988$)$ made them fragile and, consequently, their handling was difficult. When they were heated at $300^{\circ} \mathrm{C}$ for $1 \mathrm{~h}$, or at $400^{\circ} \mathrm{C}$ for $30 \mathrm{~min}$, the targeted zone did not separate from the rest of the shell. Although the material of interest was also separated at $400^{\circ} \mathrm{C}$ for $1 \mathrm{~h}$, a better shell consistency was obtained at $350^{\circ} \mathrm{C}$ for $1 \mathrm{~h}$.

The isolated section of one valve supplied an average of $4.2 \mathrm{mg}$ of material. However, depending on the detection limits of the available analytical instrument, one or several valves can be pooled for the analysis (Rivero, 1999). The maximum length in the growth direction of the separated nacreous band was $2-3 \mathrm{~mm}$ (fig. 1b). Measurements performed in our laboratory indicate that the nacreous layer of shells $50-80 \mathrm{~mm}$ in length grows $90 \%$ lengthwise with respect to the total length of the shell. Hence, the $2-3 \mathrm{~mm}$ separated section represents a total growth of 2.2 to $3.3 \mathrm{~mm}$ in length. The period of time that the isolated section represents, in terms of mussel metal accumulation, will depend on the average growth rate of the organisms in the selected site which, in turn, will depend on the environmental conditions (Behrens-Yamada and Dunham, 1989), and the initial lengths of the organisms (Coe and Fox, 1942). Based on literature values (Coe and Fox, 1942; Behrens-Yamada and Dunham, 1989), we estimate that for the organisms analyzed in the present study, each isolated section probably represents 1 to 3 months in growth.

The method developed in this study to separate a section of the most recently deposited nacreous layer from the shell of $M$. californianus is fast and simple. This technique was applied to shells from organisms used in an experiment performed in our laboratory, where M. californianus were exposed for 60 days to three different dissolved $\mathrm{Cd}$ concentrations: 0.05 (control), 1 and $20 \mu \mathrm{g} \mathrm{L}^{-1}$. Analysis of the most recently deposited nacreous layers showed significant increases in their $\mathrm{Cd}$ concentrations $\left(0.078 \pm 0.016\right.$ and $0.162 \pm 0.018 \mu \mathrm{g} \mathrm{g} \mathrm{g}^{-1}$, respectively) relative to the control $\left(0.033 \pm 0.006 \mu \mathrm{g} \mathrm{g}^{-1}\right)$ (fig. 2). The proposed method represents a valuable tool for processing large number of valves and, more important, it can be applied
(Crenshaw, 1980). La acidificación produce la disolución del $\mathrm{CaCO}_{3}$ recién depositado (Wilbur y Saleuddin, 1983) y, por tanto, también de los metales asociados con este material. La presencia de reparaciones indica que el agua de mar podría haber estado en contacto con la cara interna de la concha, y los metales traza depositados en la capa de nácar pueden representar una incorporación pasiva de metales a la misma, además de la que resulta del metabolismo del organismo. Por esta razón se decidió separar sólo una sección en vez de raspar toda la superficie interna de la capa de nácar como lo ha propuesto Bourgoin (1988).

El procedimiento para la separación óptima de la sección más reciente de la capa de nácar consiste en calentar las conchas en una mufla a $350^{\circ} \mathrm{C}$ por $1 \mathrm{~h}$. Con este tratamiento las valvas conservan su integridad (facilitando su manejo) y la sección de interés permaneció esencialmente intacta, lo que permitió separarla con facilidad del resto de la concha al golpearla suavemente con una aguja de acero inoxidable. A temperaturas y tiempos mayores $\left(400^{\circ} \mathrm{C}\right.$ por $18 \mathrm{~h}$, de acuerdo con Bourgoin, 1988) se volvieron frágiles y resultó más difícil
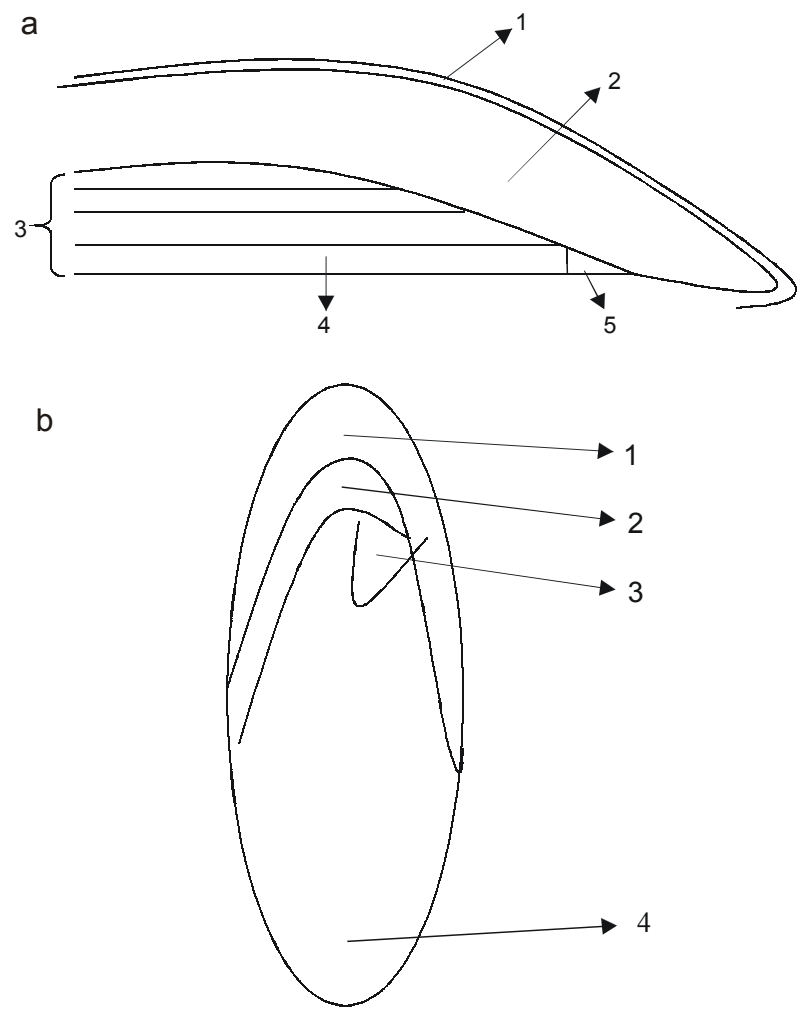

Figure 1. (a) Simplified lateral view of the shell of Mytilus californianus: 1. periostracum; 2. outer calcite layer; 3 . nacreous layer; 4. inner calcite layer; 5. section of the nacreous layer isolated in this study. (b) Internal face of a valve: 1 . calcite area; 2 . isolated nacreous section; 3 . abductor muscle zone; 4 . beak region.

Figura 1. (a) Vista lateral simplificada de la concha de Mytilus californianus: 1. periostraco; 2. capa calcítica exterior; 3. capa de nácar; 4. capa calcítica interior; 5 . sección de la capa de nácar aislada en este estudio. (b) Cara interna de una valva: 1. área calcítica; 2 . sección de nácar aislada; 3. zona del músculo abductor; 4. región del umbo. 


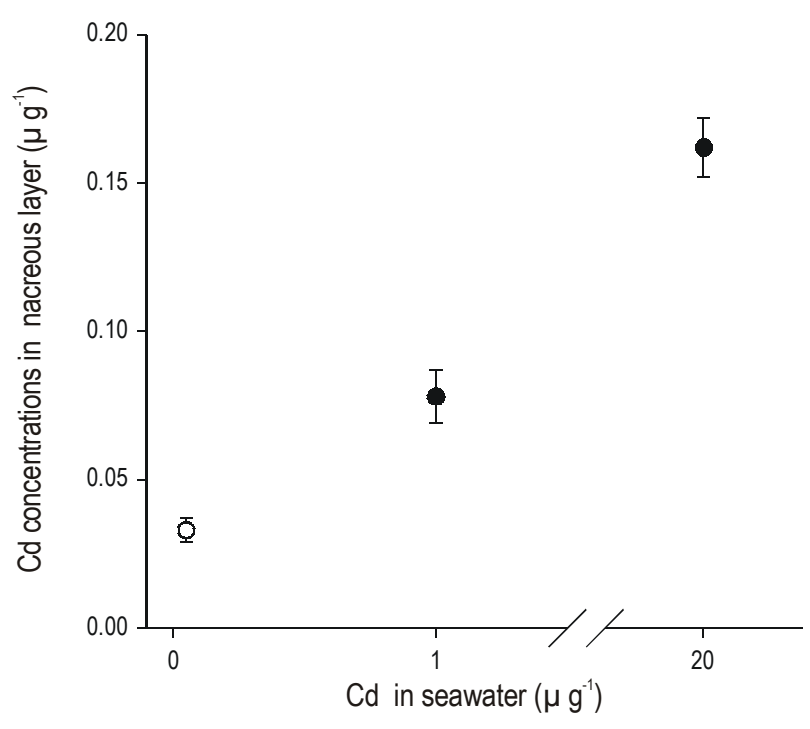

Figure 2. Concentrations of $\mathrm{Cd}$ (mean \pm 1 standard error) in the recently deposited nacreous layer of Mytilus californianus shells exposed to 0.05 (control, open symbol), 1 and $20 \mu \mathrm{g} \mathrm{L}^{-1}$ of seawater $\mathrm{Cd}$ for 60 days. Values represent the mean of three replicates, each one composed of 10 valves.

Figura 2. Concentraciones de $\mathrm{Cd}$ (media \pm 1 error estándar) en la capa de nácar recientemente depositada de conchas de Mytilus californianus expuestas durante 60 días a 0.05 (control, símbolo abierto), 1 y $20 \mu \mathrm{g} \mathrm{L}^{-1}$ de $\mathrm{Cd}$ en agua de mar. Los valores representan la media de tres réplicas, cada una compuesta de 10 valvas.

even in shells that are not in good external and internal conditions due to the high-energy environment where $M$. californianus species is normally found.

\section{References}

Babukutty, Y. and Chacko, J. (1992). Trace metals in an estuarine bivalve from the southwest coast of India. Ambio, 21: 292-296.

Behrens-Yamada, S. and Dunham, J.B. (1989). Mytilus californianus, a new aquaculture species? Aquaculture, 81: 275-283.

Bourgoin, B.P. (1988). A rapid and inexpensive technique to separate the calcite and nacreous layers in Mytilus edulis shells. Mar. Environ. Res., 25: 125-129.

Bourgoin, B.P. (1990). Mytilus edulis shell as a bioindicator of lead pollution: Considerations on bioavailability and variability. Mar. Ecol. Prog. Ser., 61: 253-262.

Coe, W.R. and Fox, D.L. (1942). Biology of the California sea-mussel (Mytilus californianus). J. Exp. Zool., 90: 1-29.

Crenshaw, M. (1980). Mechanisms of shell formation and dissolution. In: D.C. Rhoads and R.A. Lutz (eds.), Skeletal Growth of Aquatic Organisms. Plenum Press, New York, pp. 115-132.

Dodd, J.R. (1964). Environmentally controlled variation in the shell structure of a pelecypod species. J. Paleontol., 38: 1065-1071.

Lares, M.L. and Orians, K.J. (1997). Natural $\mathrm{Cd}$ and $\mathrm{Pb}$ variations in Mytilus californianus during the upwelling season. Sci. Total Environ., 197: 177-195.

Puente, X., Villares, R., Carral, E. and Carballeira, A. (1996) Nacreous shell of Mytilus galloprovincialis as a biomonitor of heavy metal pollution in Galiza (NW Spain). Sci. Total Environ., 183: 205-211. su manejo. Cuando se calentaron a $300^{\circ} \mathrm{C}$ por $1 \mathrm{~h}$ ó a $400^{\circ} \mathrm{C}$ por $30 \mathrm{~min}$, la sección de interés no se separó del resto de la concha, y a pesar de que sí se separó a $400^{\circ} \mathrm{C}$ por $1 \mathrm{~h}$, se obtuvo una mejor consistencia de concha a $350^{\circ} \mathrm{C}$ por $1 \mathrm{~h}$.

La sección aislada de una valva proporcionó $4.2 \mathrm{mg}$ de material en promedio; sin embargo, según los límites de detección del instrumental analítico disponible, se pueden combinar una o varias valvas para el análisis (Rivero, 1999). La máxima longitud en la dirección de crecimiento de la sección de nácar separada fue de 2 a $3 \mathrm{~mm}$ (fig. 1b). Las mediciones realizadas en nuestro laboratorio muestran que la capa de nácar de conchas de 50 a $80 \mathrm{~mm}$ crece $90 \%$ a lo largo con respecto a la longitud total de la concha. Así, la sección de 2 a $3 \mathrm{~mm}$ separada representa un crecimiento total de 2.2 a $3.3 \mathrm{~mm}$ de longitud. El periodo de tiempo que representa la sección aislada, en términos de acumulación de metales por el mejillón, dependerá de la tasa de crecimiento media del organismo en la localidad seleccionada (Behrens-Yamada y Dunham, 1989) y de las longitudes iniciales de los organismos (Coe y Fox, 1942). Con base en valores de la literatura (Coe y Fox, 1942; Behrens-Yamada y Dunham, 1989), se estima que para los organismos analizados en este estudio, cada sección aislada probablemente representa de 1 a 3 meses de crecimiento.

El método desarrollado en este trabajo resultó un procedimiento simple y rápido para separar la capa de nácar recientemente depositada del resto de la concha de $M$. californianus, y sirvió para determinar bioacumulación en un experimento de laboratorio, en el cual mejillones de $M$. californianus fueron expuestos durante 60 días a tres diferentes concentraciones de Cd disuelto: 0.05 (control), 1 y $20 \mu \mathrm{g} \mathrm{L}^{-1}$. El análisis de las capas de nácar recientemente depositadas mostró un aumento significativo en sus concentraciones de $\mathrm{Cd}$ $\left(0.078 \pm 0.016\right.$ y $0.162 \pm 0.018 \mu \mathrm{g} \mathrm{g}^{-1}$ para las dos últimas concentraciones, respectivamente) con respecto al control $(0.033 \pm$ $0.006 \mu \mathrm{g} \mathrm{g}^{-1}$ ) (fig. 2). El método propuesto resulta una herramienta valiosa para procesar un gran número de valvas $\mathrm{y}$, aún más importante, se puede utilizar en conchas que no se encuentran en buenas condiciones externas e internas debido al ambiente de alta energía donde normalmente habita $M$. californianus.

Traducido al español por Christine Harris.

Rivero, L.E. (1999). Comparación de la concentración de Cd entre el tejido blando y la concha de Mytilus californianus en una zona de surgencias. M.Sc. thesis, Centro de Investigación Científica y de Educación Superior de Ensenada, Mexico, 81 pp.

Sturesson, U. (1976). Lead enrichment in shells of Mytilus edulis. Ambio, 5: 253-256.

Sturesson, U. (1978). Cadmium enrichment in shells of Mytilus edulis. Ambio, 7: 122-125.

Wilbur, K.M. and Saleuddin, A.S.M. (1983). Shell formation. In: K.M. Wilbur (ed.), The Mollusca - Physiology. Vol. 4. Academic Press, New York, pp. 235-287. 